\title{
Antioxidant activity of citron peel (Citrus medica L.) essential oil and extract on stabilization of sunflower oil
}

\author{
Somayeh Okhli ${ }^{1}$, Habibollah Mirzaei ${ }^{2,{ }^{*}}$ and Seyed Ebrahim Hosseini ${ }^{3}$ \\ ${ }^{1}$ Department of Food Science and Technology, Sari Branch, Islamic Azad University, Sari, Iran \\ 2 Gorgan University of Agricultural Sciences and Natural Resources, Gorgan, Iran \\ ${ }^{3}$ Food Science and Technology, Islamic Azad University, Science and Research Branch, Tehran, Iran
}

Received 29 December 2019 - Accepted 6 April 2020

\begin{abstract}
Due to the unfavorable effects of synthetic antioxidants, the use of various sources of plant antioxidants to prevent foods oxidation, especially oil-based or fat-based varieties, has been recently got considerable attention. In this study, the antioxidant effect of essential oil and extract from the citron fruit (Citrus medica L.) was investigated on the thermal stability of sunflower oil. Aqueous, ethanolic, and methanolic extracts of citron peel ( $800 \mathrm{ppm})$, BHT synthetic antioxidant $(200 \mathrm{ppm})$, and citron peel essential oil $(800 \mathrm{ppm})$ were added to sunflower oil. The oil oxidation stability was evaluated during 5 days through analyzing the values of peroxide, anisidine, thiobarbituric acid, totox, and oxidative stability index (OSI). Results showed that the peroxide, anisidine, and totox value had an increasing trend over time. The effects of storage time, extract, and essential oil were statistically significant in reducing the oxidation rate of sunflower oil during storage. Ultrasonic-assisted ethanolic extract at $30 \mathrm{~min}$ showed the highest OSI. The results of this study demonstrated the positive effects of citron peel extract essential oil and on sunflower oil stability and its superiority over synthetic antioxidants.
\end{abstract}

Keywords: citron peel / sunflower oil / natural antioxidant / essential oil / thermal stability

Résumé - Activité antioxydante de l'huile essentielle et de l'extrait d'écorce de cédrat (Citrus medica L.) sur la stabilisation de l'huile de tournesol. En raison des effets défavorables des antioxydants synthétiques, l'utilisation de diverses sources d'antioxydants végétaux pour prévenir l'oxydation des aliments, en particulier les variétés à base d'huile ou de graisse, a récemment fait l'objet d'une attention considérable. Dans cette étude, l'effet antioxydant de l'huile essentielle et de l'extrait du fruit du cédrat (Citrus medica L.) a été étudié sur la stabilité thermique de l'huile de tournesol. Des extraits aqueux, éthanoliques et méthanoliques d'écorces de cédrat $(800 \mathrm{ppm})$, un antioxydant synthétique BHT (200 ppm) et de l'huile essentielle d'écorces de cédrat $(800 \mathrm{ppm})$ ont été ajoutés à l'huile de tournesol. La stabilité de l'huile à l'oxydation a été évaluée pendant 5 jours en analysant les indices de peroxyde, d'anisidine, d'acide thiobarbiturique, le paramètre TotOx (Total Oxydation) et l'indice de stabilité à l'oxydation (OSI). Les résultats ont montré que les indices de peroxyde, d'anisidine et de TotOx avaient une tendance à la hausse au fil du temps. Les effets du temps de stockage, des différents extraits et de l'huile essentielle étaient statistiquement significatifs dans la réduction du taux d'oxydation de l'huile de tournesol pendant le stockage. L'extrait éthanolique assisté par ultrasons a montré l'OSI le plus élevé à $30 \mathrm{~min}$. Les résultats de cette étude ont démontré les effets positifs de l'huile essentielle et de l'extrait d'écorce de cédrat sur la stabilité de l'huile de tournesol et sa supériorité par rapport aux antioxydants synthétiques.

Mots clés : écorce de cédrat / huile de tournesol / antioxydant naturel / huile essentielle / stabilité thermique

\footnotetext{
*Correspondence: habibollah.20200@gmail.com
} 


\section{Introduction}

Citrus medica is a type of citrus fruits consisting of two parts including the outer layer, which is an important part of citron in international trade, and the other layer is the pulp as an edible part of the fruit and a good source of pectin (Abdul, 2014). C. medica has long been used for medical purposes, for example, to combat seasickness, lung problems, intestinal diseases, and other disorders. Flavored essential oils of this fruit (located in the outermost, pigmented layer of the peel) are also considered as antibiotics. Citron peel contains citronellal, terpenes, aldehydes, ketones, esters, alcohols, organic acids, etc. Limonene counteracts the effect of pathogenic microorganisms and contains terpenes, sesquiterpene aliphatic terpenes, oxygenated derivatives, bicyclic terpenes, nonterpene aliphatic components, aromatic hydrocarbons, and nitrogen-containing esters. Geraniol and other monoterpenes found in citron fruit peel extract are reported to have anticancer properties (Meena et al., 2011).

Oils are important components of human diets that are used either directly (e.g. frying processes) or in combination with other components (such as biscuits). Because of unsaturated fatty acids in many oils, these substances are subject to oxidation and rancidity. If oxidation exceeds a certain level, it renders the oil or the containing material unusable for food consumption. Besides, some compounds produced by oxidation are detrimental to human health. The oxidative stability of oils can be improved by altering the composition of oil fatty acids or by applying antioxidants as supplementing (Chung et al., 2004).

Butylated hydroxyl anisole (BHA), butylated hydroxyl toluene (BHT), and tertiary butylhydroquinone (TBHQ) are the most common synthetic antioxidants, which are usually added to the oil after the deodorization process. According to Suja et al. (2004), the use of these antioxidants, despite their effective role in prevention of oils oxidation, may be associated with carcinogenic, mutagenic, or other effects on humans under certain conditions. Therefore, the enrichment of oils with substances containing high amounts of natural antioxidant compounds increasing oxidative stability of oils (Mir-Ahmadi et al., 2005). Sunflower oil is one of the most widely used vegetable oils in the industry that can withstand high cooking temperatures and is, therefore, a desirable option for the frying process. Sunflower oil also has advantages than other frying oils, including fewer contents of saturated fatty acids and the uppermost vitamin E content (Johnson et al., 2009).

A considerable number of studies have focused on the antioxidant capacity of extracts and essential oils and replacement of synthetic antioxidants with plant bioactive compounds (Mallet et al., 1994). Popovich (2008) investigated the antioxidant properties of parsley, thyme, and fennel on sunflower oil and found that the natural antioxidants of these plants were effective in sunflower oil stability. Oktaya et al. (2003) studied the antioxidant properties of ethanolic and aqueous extracts of fennel seeds through total antioxidant capacity, free radical scavenging capacity, superoxide anion radical scavenging, hydrogen peroxide inhibition, and metal chelating activity tests, and compared them with alphatocopherol and synthetic antioxidants (BHT and BHA). They
Table 1. Independent variables with corresponding codes.

\begin{tabular}{lll}
\hline Treatments code & Solvents & Ultrasonic time (min) \\
\hline T1 & Ethanol & 10 \\
T2 & Ethanol & 20 \\
T3 & Ethanol & 30 \\
T4 & Methanol & 10 \\
T5 & Methanol & 20 \\
T6 & Methanol & 30 \\
T7 & Water & 10 \\
T8 & Water & 20 \\
T9 & Water & 30 \\
T10 & & BHT \\
T11 & & Essential oil \\
\hline
\end{tabular}

reported that the antioxidant properties of fennel were concentration-dependent and increased with rising concentrations.

Due to the important role of edible fats in diets and adverse effects of synthetic antioxidants on human health, in this study, the antioxidant effect of essential oil and extract from citron fruit peel was evaluated on thermal stability of sunflower oil.

\section{Materials and methods}

\subsection{Materials}

Citron fruit (Citrus medica L.) was obtained from a local market in Tehran. The materials used in this study were procured from the Merck Company, Germany.

\subsection{Methods}

\subsubsection{Preparation of the citron peel ethanolic extract}

The inner peel (mesocarp) of $C$. medica was separated, dried completely at $45^{\circ} \mathrm{C}$ in a dryer (Memmert 800, Germany), powdered by an electric mill (Eka, Germany), and the powder was passed through a sieve (Mesh-80).

Citron peel was extracted using an ultrasound bath (DT 255 $\mathrm{H}$, Bandelin Co., Germany). The peel powder ( $40 \mathrm{~g})$ with $400 \mathrm{ml}$ of ethanol, methanol, and water were exposed to ultrasound with a frequency of $40 \mathrm{kHz}$ for 10,20 , and 30 minutes (Albu et al., 2004). The extracts were then filtered by Whatman Grade 42 filter papers. The residue was reextracted under identical conditions and the solvent residue was vacuum-evaporated with a rotary evaporator (Heidolph, Germany). After solvent evaporation, the extract was kept frozen at $-18^{\circ} \mathrm{C}$ until use (Rehman, 2006). Table 1 represents the independent variables with the corresponding codes.

\subsubsection{Preparation of essential oil from citron peel}

Citron peel essential oil was prepared using a Clevenger apparatus (Brosilicat, Germany) and steam distillation. To this end, $100 \mathrm{~g}$ of the dried plant was poured into the balloon of the apparatus along with adding water, and the essential oil was extracted during $2 \mathrm{~h}$ (Hokmollahi, 2010). 


\subsubsection{Preparation of treatments}

Aqueous, ethanolic, and methanolic extracts of citron fruit peel at $800 \mathrm{ppm}$, BHT synthetic antioxidant at $200 \mathrm{ppm}$, and citron peel essential oil at $800 \mathrm{ppm}$ were added to sunflower oil. The oil oxidation stability was evaluated every $24 \mathrm{~h}$ for 5 days at $65^{\circ} \mathrm{C}$ by analyzing the values of peroxide, anisidine, thiobarbituric acid (TBA), totox, and oxidative stability index (OSI).

\subsection{Tests}

\subsubsection{Peroxide index}

In this test, the concentrations of peroxide and hydroperoxides formed in the initial stage of reaction were measured and expressed in milli-equivalents peroxide per $\mathrm{kg}$ of fat. The value of this index was calculated according to the reference method (AOCS, 2003, cd 8-53) during the storage (Matthaus, 2006).

\subsubsection{Anisidine index}

The sample $(0.5 \mathrm{~g})$ was weighed accurately in a $5 \mathrm{ml}$ volumetric flask, then dissolved in isooctane, reached a volume, and mixed well. The absorption of the fat solution against pure isooctane was read at $350 \mathrm{~nm}$ with a spectrophotometer (JENWAY uv/vis, 6305, England) (a). The solution ( $5 \mathrm{ml}$ ) and isooctane $(5 \mathrm{ml})$ were poured into test tubes $A$ and $B$, respectively. One milliliter of anisidine was added to two tubes, shaken vigorously, and put in a dark place for 10 minutes. The absorbance of tube A content versus tube B was measured at $350 \mathrm{~nm}$ in a $1 \mathrm{~cm}$ glass cell (b). The anisidine index was calculated by the following equation:

$$
\text { Anisidine index }=\frac{25(1.2 \mathrm{~A} 1-\mathrm{A} 2)}{m},
$$

where, $A_{1}$ and $A_{2}$ represent the absorption of test solutions (b) and (a), respectively, at $350 \mathrm{~nm}$, and $m$ is the mass (g) of the test substance in test solution (a) (Dieffenbacher and Pocklington, 1987).

\subsubsection{Totox index}

The totox index was calculated using peroxide and anisidine indices according to the following equation (AOCS, 1998):

Totox index $=2($ peroxide index $)+$ anisidine index .

\subsubsection{Thiobarbituric acid (TBA) index}

The TBA value was determined through the direct method using butanol as a solvent in the presence of TBA reagent by measuring the absorbance of the solution at $350 \mathrm{~nm}$ wavelength versus a blank (the solvent and reaction solution) with a spectrophotometer (AOCS, 1998, cd 19-90). The results were calculated using the following equation:

$$
\text { TBA value }=\frac{50(\mathrm{~A}-\mathrm{B})}{m},
$$

where TBA denotes thiobarbituric acid value, A and B are respectively the absorbance of test and blank solutions at $530 \mathrm{~nm}$, and $m$ is sample mass (mg).

\subsubsection{Thermal stability}

Oxidative stability of oil samples was measured using a Rancimat device (Metrohm Rancimat 743, Switzerland) according to the AOCS method (AOCS, 1998).

\subsection{Statistical analysis}

All experiments were conducted in triplicate and an analysis of variance was performed. The least significant difference at $p<0.05$ was calculated using the Duncan Multiple Range Test on SPSS software version 20. The charts were drawn by Excel software (2010).

\section{Results and discussion}

\subsection{Peroxide index of sunflower oil samples}

Table 2 shows the changes in the peroxide index of sunflower oil containing the extract and essential oil of citron peel during storage at $65^{\circ} \mathrm{C}$. Statistically significant difference of peroxide values were measured in samples containing ethanolic, methanolic, and aqueous extracts from zero to 5 days, which increased by rising time. On the second day of storage, the ethanolic sample extracted by ultrasound had the lowest peroxide index at $30 \mathrm{~min}$. The highest peroxide value was observed in the aqueous extract with increasing storage time at the end of the fifth day.

The use of water for extraction created a completely polar environment; consequently, some phenolic compounds with low polarity were extracted in minor quantities. In addition, aqueous extracts contain such impurities as organic acids, proteins, and soluble sugars (Chirinos et al., 2007). However, ethanol and methanol with water are more capable of extracting phenolic compounds (Suzuki et al., 2002). The accumulation of phenolic compounds will reduce the peroxide value. The decrease of the oil peroxide index in the samples resulted from the antioxidant activity and phenolic compounds present in the extract of citron fruit peel. Nevertheless, antioxidants compounds remain active for a certain period and gradually lose their effects over the time, which may be related the storage of samples under heat conditions storage. Thus, increasing the storage time of oil samples under oxidation conditions led to an increased peroxide index. Esmaeilzadeh Kenari and Mehdipoor (2012) investigated the antioxidant properties of kiwifruit peel to stabilize sunflower oil and observed increased peroxide value with rising the storage time. Abdalla and Roozen (1999) also confirmed the efficacy of natural essential oils and extracts in preventing the oxidation of edible oils compared to synthetic antioxidants. In another study, it was shown that peroxide values in control oil samples were higher than those of oil samples containing BHT and anemone plant extract, with the lowest peroxide value belonging to extract-containing samples (Agregán et al., 2017), this finding was in agreement with our findings. 
Table 2. Comparison of peroxide values (meq $\mathrm{O}_{2} / \mathrm{kg}$ ) in treatments during 5 days of storage. (uppercase and lowercase letters show significant differences in each row and column, respectively, at $p<0.05)$.

\begin{tabular}{|c|c|c|c|c|c|}
\hline Treatments & First day & Second day & Third day & Fourth day & Fifth day \\
\hline $\mathrm{T} 2$ & $2.30 \pm 0.09^{\mathrm{D}, \mathrm{f}}$ & $2.16 \pm 0.05^{\mathrm{D}, \mathrm{d}}$ & $2.90 \pm 0.04^{\mathrm{C}, \mathrm{f}}$ & $3.10 \pm 0.08^{\mathrm{B}, \mathrm{fg}}$ & $4.61 \pm 0.06^{\mathrm{A}, \mathrm{e}}$ \\
\hline $\mathrm{T} 4$ & $3.20 \pm 0.09^{\mathrm{D}, \mathrm{c}}$ & $3.26 \pm 0.05^{\mathrm{D}, \mathrm{b}}$ & $3.71 \pm 0.02^{\mathrm{C}, \mathrm{b}}$ & $3.76 \pm \pm 0.02^{\mathrm{B}, \mathrm{c}}$ & $5.10 \pm 0.06^{\mathrm{A}, \mathrm{c}}$ \\
\hline $\mathrm{T} 5$ & $1.81 \pm 0.07^{\mathrm{E}, \mathrm{i}}$ & $2.10 \pm 0.09^{\mathrm{D}, \mathrm{de}}$ & $2.61 \pm 0.04^{\mathrm{C}, \mathrm{gh}}$ & $3.22 \pm 0.07^{\mathrm{B}, \mathrm{f}}$ & $4.20 \pm 0.07^{\mathrm{A}, \mathrm{f}}$ \\
\hline $\mathrm{T} 8$ & $4.10 \pm 0.06^{\mathrm{B}, \mathrm{a}}$ & $3.46 \pm 0.04^{\mathrm{D}, \mathrm{a}}$ & $3.61 \pm 0.06^{\mathrm{C}, \mathrm{c}}$ & $4.20 \pm 0.08^{\mathrm{B}, \mathrm{a}}$ & $5.60 \pm 0.07^{\mathrm{A}, \mathrm{a}}$ \\
\hline T9 & $2.60 \pm 0.03^{\mathrm{C}, \mathrm{e}}$ & $2.34 \pm 0.05^{\mathrm{D}, \mathrm{c}}$ & $2.51 \pm 0.06^{\mathrm{C}, \mathrm{h}}$ & $3.40 \pm 0.03^{\mathrm{B}, \mathrm{e}}$ & $4.60 \pm 0.08^{\mathrm{A}, \mathrm{e}}$ \\
\hline $\mathrm{T} 10$ & $1 / 91 \pm 0.02^{\text {E,h }}$ & $2.15 \pm 0.04^{\mathrm{D}, \mathrm{d}}$ & $3.30 \pm 0.04^{\mathrm{C}, \mathrm{d}}$ & $3.81 \pm 0.06^{\mathrm{B}, \mathrm{bc}}$ & $4.73 \pm 0.03^{\mathrm{A}, \mathrm{d}}$ \\
\hline $\mathrm{T} 11$ & $2.10 \pm 0.07^{\mathrm{E}, \mathrm{g}}$ & $2.21 \pm 0.03^{\mathrm{D}, \mathrm{d}}$ & $3.10 \pm 0.09^{\mathrm{C}, \mathrm{e}}$ & $3.60 \pm 0.07^{\mathrm{B}, \mathrm{d}}$ & $4.73 \pm 0.04^{\mathrm{A}, \mathrm{d}}$ \\
\hline
\end{tabular}

Table 3. Comparison of anisidine values (meq $/ \mathrm{kg}$ ) in treatments during 5 days of storage. (uppercase and lowercase letters show significant differences in each row and column, respectively, at $p<0.05$ ).

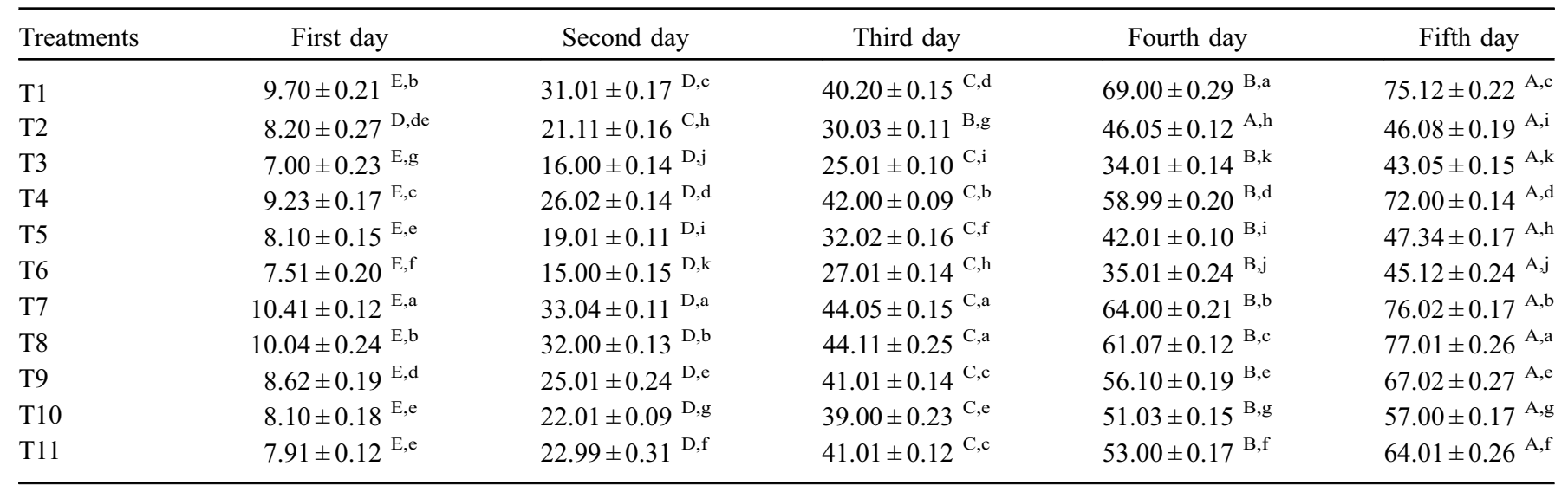

The peroxide value of BHT synthetic antioxidant sample increased from an initial value of 1.91 to $4.73 \mathrm{meq} \mathrm{O}_{2} / \mathrm{kg}$ oil after 5 days of oil storage at $65^{\circ} \mathrm{C}$. Peroxide value was increased by statistically significant differences in oil samples containing ethanolic, methanolic, and aqueous extracts at sonication of $30 \mathrm{~min}$, from an initial value of 0.7 to $3.6,3.9$, and $4.6 \mathrm{meq} \mathrm{O}_{2} / \mathrm{kg}$ oil, respectively, after 3 days of storage at $65^{\circ} \mathrm{C}$. Peroxide value resulted from citron peel essential oil added to sunflower oil was similar to BHT addition.

Peroxide value cannot indicate oil oxidation because it is an indicator of the presence of primary oxidation products and does not reveal the production of secondary products. Because of the decomposition of hydroperoxides at high temperatures and the formation of secondary compounds (e.g. aldehydes), a test such as an anisidine index seems to be necessary as an indicator of oxidation development (Matthaus, 2006).

\subsection{Anisidine values f sunflower oil samples}

Based on the results of ANOVA (Tab. 3), changes in the anisidine index of sunflower oil stored at $65^{\circ} \mathrm{C}$ were significantly affected by the extract of citron fruit peel $(p<0.05)$. The anisidine values were different in the oil samples and had an increasing trend in all samples by rising storage time at $65^{\circ} \mathrm{C}$. On the first storage day, oil samples containing ethanolic extract had the lowest anisidine index. The highest anisidine value was observed in the oil-containing aqueous extract by increasing storage time at the end of the fifth day. The anisidine index rose from an initial, pre-oven value of 10.04 to $77.01(p<0.05)$.

The anisidine values of extracts were significantly different at the end of 5-day storage at $65^{\circ} \mathrm{C}(p<0.05)$. The highest $(77.01 \mathrm{meq} / \mathrm{kg})$ and the lowest $(43.05 \mathrm{meq} / \mathrm{kg})$ anisidine indices were recorded in the oils containing aqueous and methanolic extracts, respectively. The index was low in the early days and rose in the final days.

An increase in anisidine index indicates the expansion of spontaneous oxidation reaction leading to the increase of secondary products resulting from the decomposition of hydroperoxides and carbonyl compounds during the time (Namiki, 1990). Tahami et al. (2011) evaluated the antioxidant effect of fennel seed extract on sunflower oil stability value. They reported higher efficacy of fennel seed extract than both 
Table 4. Comparison of totox values (meq $/ \mathrm{kg}$ ) in treatments during 5 days of storage. (uppercase and lowercase letters show significant differences in each row and column, respectively, at $p<0.05)$.

\begin{tabular}{|c|c|c|c|c|c|}
\hline Treatments & First day & Second day & Third day & Fourth day & Fifth day \\
\hline $\mathrm{T} 2$ & $12.81 \pm 0.26^{\mathrm{E}, \mathrm{e}}$ & $25.42 \pm 0.18^{\mathrm{D}, \mathrm{h}}$ & $35.81 \pm 0.24^{\mathrm{C}, \mathrm{g}}$ & $52.20 \pm 0.33^{\mathrm{B}, \mathrm{h}}$ & $55.22 \pm 0.31^{\mathrm{A}, \mathrm{h}}$ \\
\hline $\mathrm{T} 4$ & $15.61 \pm 0.24^{\mathrm{E}, \mathrm{c}}$ & $32.51 \pm 0.26^{\mathrm{D}, \mathrm{d}}$ & $49.42 \pm 0.28^{\mathrm{C}, \mathrm{c}}$ & $66.52 \pm 0.37^{\mathrm{B}, \mathrm{d}}$ & $84.31 \pm 0.35^{\mathrm{A}, \mathrm{c}}$ \\
\hline T5 & $11.70 \pm 0.38^{\mathrm{E}, \mathrm{f}}$ & $23.20 \pm 0.45^{\mathrm{D}, \mathrm{i}}$ & $37.23 \pm 0.23^{\mathrm{C}, \mathrm{f}}$ & $48.44 \pm 0.39^{\mathrm{B}, \mathrm{i}}$ & $55.70 \pm 0.23^{\mathrm{A}, \mathrm{h}}$ \\
\hline $\mathrm{T} 8$ & $18.20 \pm 0.26^{\mathrm{E}, \mathrm{a}}$ & $38.92 \pm 0.19^{\mathrm{D}, \mathrm{b}}$ & $51.22 \pm 0.39^{\mathrm{C}, \mathrm{b}}$ & $77.80 \pm 0.28^{\mathrm{B}, \mathrm{b}}$ & $88.20 \pm 0.17^{\mathrm{A}, \mathrm{a}}$ \\
\hline T9 & $13.80 \pm 0.29^{\mathrm{E}, \mathrm{d}}$ & $29.68 \pm 0.24^{\mathrm{D}, \mathrm{e}}$ & $46.02 \pm 0.27^{\mathrm{C}, \mathrm{e}}$ & $62.91 \pm 0.34^{\mathrm{B}, \mathrm{e}}$ & $76.20 \pm 0.21 \mathrm{~A}, \mathrm{e}$ \\
\hline $\mathrm{T} 10$ & $11.91 \pm 0.14^{\mathrm{E}, \mathrm{f}}$ & $26.31 \pm 0.30^{\mathrm{D}, \mathrm{g}}$ & $45.60 \pm 0.33^{\mathrm{C}, \mathrm{e}}$ & $58.63 \pm 0.22^{\mathrm{B}, \mathrm{g}}$ & $66.47 \pm 0.16^{\mathrm{A}, \mathrm{g}}$ \\
\hline $\mathrm{T} 11$ & $12.11 \pm 0.31^{\mathrm{E}, \mathrm{f}}$ & $27.42 \pm 0.28^{\mathrm{D}, \mathrm{f}}$ & $47.20 \pm 0.51^{\mathrm{C}, \mathrm{d}}$ & $60.26 \pm 0.48^{\mathrm{B}, \mathrm{f}}$ & $73.47 \pm 0.46^{\mathrm{A}, \mathrm{f}}$ \\
\hline
\end{tabular}

Table 5. Comparison of TBA index ( $\mathrm{mg} \mathrm{MA} / \mathrm{kg}$ ) in treatments during 5 days of storage (uppercase and lowercase letters show significant differences in each row and column, respectively, at $p<0.05$ ).

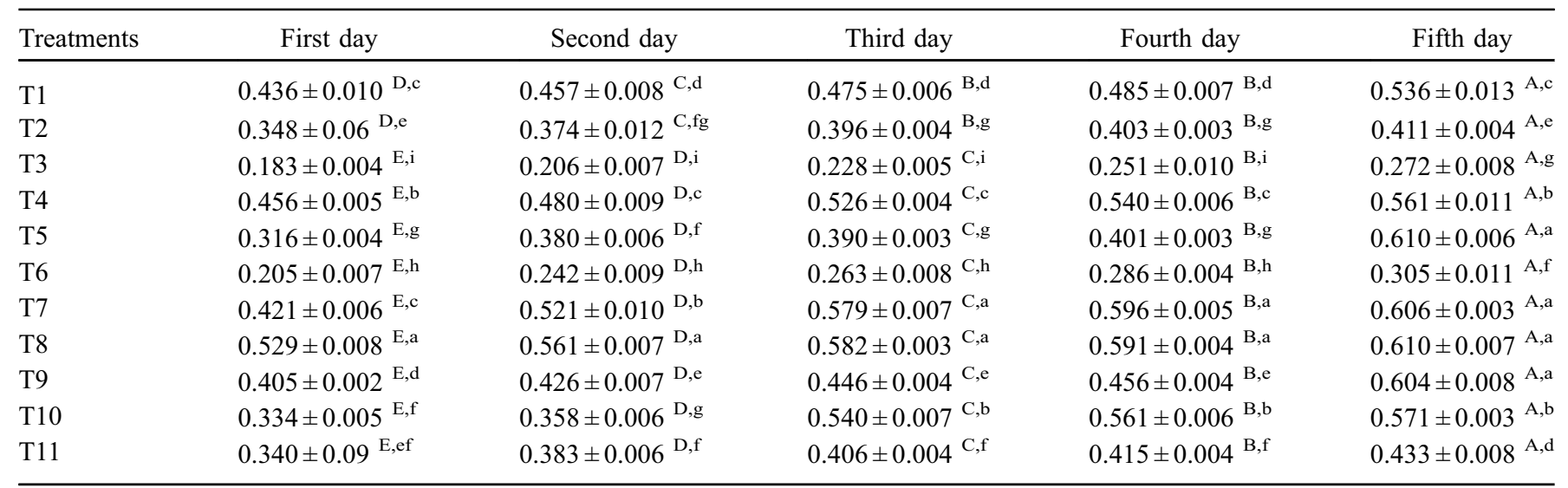

synthetic antioxidants and reduced anisidine values and peroxide values in oil samples. According to Gharekhani et al. (2009), extracts containing natural antioxidants are capable of reacting with free radicals resulting from lipid oxidation.

\subsection{Totox index of sunflower oil samples}

The results of this study revealed that the peroxide, anisidine, and totox indices had an increasing trend during time. The ethanolic extract presented the least totox values of 8.40 and 50.21 on the first and fifth days, respectively (Tab. 4). At the end of the fifth storage day, totox values were 50.22, 83.58 , and 88.20 for sunflower oil samples containing aqueous, ethanolic, and methanolic extracts, respectively, which were significantly higher than those of the first day $(p<0.05)$. On the fifth day, totox values of 66.47 and 73.47 were obtained in the sample containing synthetic antioxidant and essential oil respectively. Ethanolic extracts were more effective in preventing oil oxidative rancidity than the other treatments, particularly the synthetic antioxidant and the essential oil.

Similarly, Mazaheri Kalahrodi et al. (2014) reported that the use of fennel seed extract (at 100, 200, 300, 400, 500, 600, 700 , and $800 \mathrm{ppm}$ ) in soybean oil reduced totox values in oil samples. In their study, the extract at levels of 300 and $400 \mathrm{ppm}$ had higher antioxidant activity than BHT and BHA.

\subsection{Thiobarbituric acid (TBA) index of sunflower oil samples}

The TBA index represents the milligram of malondialdehyde in one $\mathrm{kg}$ of oil (mg MA/kg), indicating the secondary stage of lipid oxidation and the presence of secondary oxidation products in the samples. Thus, a high TBA index in the oil indicates greater oil oxidation and less stability. The results showed that the TBA index was low in the initial days as it increased due to the decomposition of formed hydroperoxides and their conversion into aldehydes and ketones in the first days (Tab. 5). As a result, this index increased in the final days and was significantly different from the other days of storage $(p<0.05)$. The ethanolic extract treatment had the highest ability to prevent the formation of secondary oxidation products. TBA values were equal to 0.183 and $0.272 \mathrm{mg} \mathrm{MA} / \mathrm{kg}$ for the ethanolic extract treatment with 30 minutes sonication time in the first and fifth days, respectively. Increased antioxidant activity of the ethanolic extract was related to the amounts of phenolic compounds in this extract; therefore, TBA index was decreased. TBA value was uppermost in the aqueous extract 


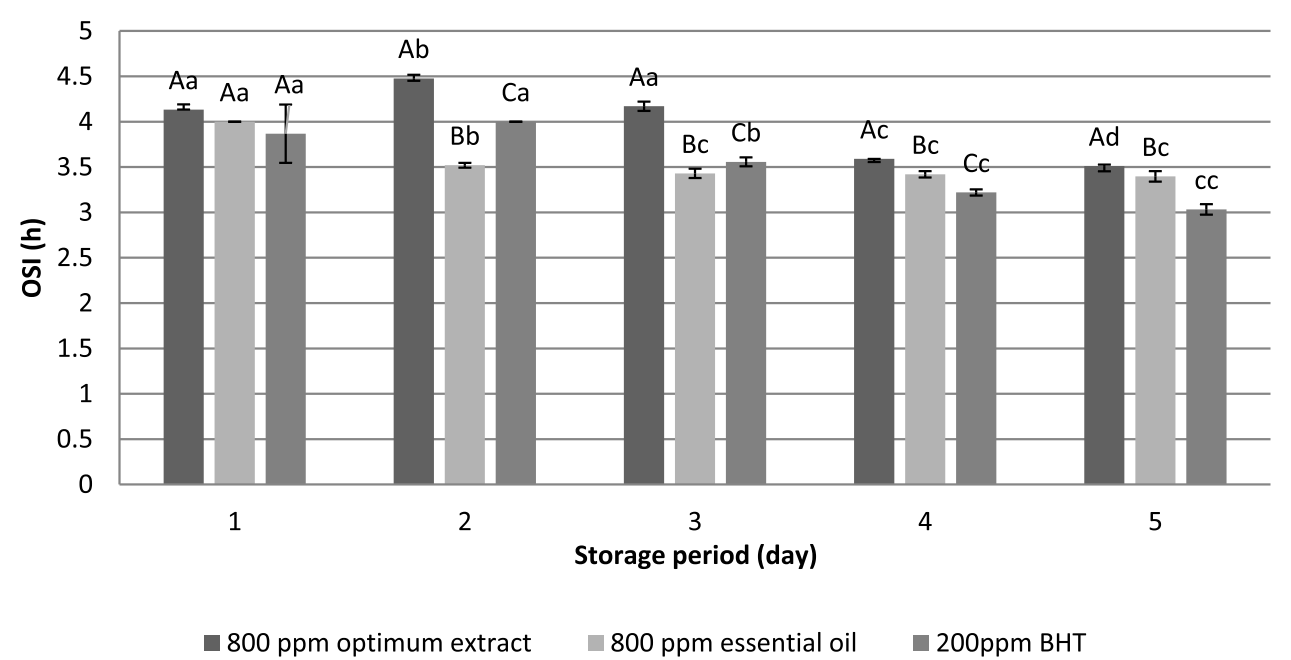

Fig. 1. Changes in oxidative stability index of sunflower oil samples during 5 days of storage at $65^{\circ} \mathrm{C}$ (different lowercase letters in the same treatment indicate significant differences $(p<0.05)$ between different time points. Different capital letters at the same time point indicate significant differences $(p<0.05)$ between different treatments).

during all days so that it increased from 0.405 , at the pre-oven stage, to $0.604 \mathrm{mg} \mathrm{MA} / \mathrm{kg}$ after $72 \mathrm{~h}$ storage of sunflower oil at $65^{\circ} \mathrm{C}$. A comparison between peroxide and TBA values reveals a direct relationship between the production of hydroperoxide and the increased TBA value.

In the ultrasonic treatments, the peroxide and TBA values were significantly lower due to further extraction of phenolic compounds in these samples. In the synthetic antioxidant sample, peroxide began to decompose as it reached a specific level by time, thereby producing aldehyde, ketone, and acid leading to a rise in TBA and a decrease in peroxide content.

In a similar study, Ayoughi et al. (2009) evaluated the antioxidant activity of dill (Anethum grareolens) essential oil in soybean oil by measuring peroxide and TBA values. They concluded that dill essential oil could prevent the production of primary and secondary oxidation products in crude soybean oil at a concentration of $0.6 \mathrm{mg} / \mathrm{ml}$, which is approximately equal to BHA chemical oxidation at a concentration of $0.1 \mathrm{mg} / \mathrm{ml}$. Sahari et al. (2004) reported a high antioxidant activity in tea seed oil that could improve sunflower oil storage. Ozcan and Arslan (2011) presented evidence that hazelnut oil samples containing clove, cinnamon, and rosemary essential oils at 0.25 and $0.5 \%$ could effectively delay the formation of primary oxidation products than the control sample. Furthermore, peppermint extract also enhanced the stability of extra virgin olive oil. Hashemi et al. (2014) also observed that the essential oil of ajwain (aniseed) reduced the oxidation rate of sunflower oil.

\subsection{Oxidative Stability Index (OSI)}

OSI is the time to reach a point that one of the oxidative quantities, like the peroxide or carbonyl value, increases abruptly after an increasing trend. Accelerated tests to investigate oxidative stability increase the speed of natural oxidation process and are important quality control tools for determining the shelf life of a product (Abdalla and Roozen, 1999). Changes in the OSI of the sunflower oil affected by the optimum extract (ethanolic extract treatment with $30 \mathrm{~min}$ ultrasound), essential oil, and BHT during the storage at $65^{\circ} \mathrm{C}$ are shown in Figure 1. A continued decrease in OSI with the increase in storage period was observed in all the samples. According to Figure 1, the lowest ( $3 \mathrm{~h}$ ) and the highest $(4.47 \mathrm{~h})$ thermal stability were recorded in the fifth day for sunflower oil containing BHT and the second day for sunflower oil containing optimum extract, which were significantly different $(p<0.05)$. In the sunflower oil containing optimum extract, the OSI decreased from baseline value $(4.13 \mathrm{~h})$ to $3.51 \mathrm{~h}$ after 5 days of storage. For the oil samples containing essential oil, however, the OSI decreased from an initial value of 4 to $3.39 \mathrm{~h}$ after 5 days of storage at $65^{\circ} \mathrm{C}$.

Tahami et al. (2011) investigated the antioxidant effect of fennel seed extract on sunflower oil stability and found that fennel extract at concentrations of 250 and $300 \mathrm{ppm}$ had a higher resistance to oxidation than synthetic antioxidants (BHT and BHA). Iqbal and Bhanger (2007) investigated the effect of garlic extract on the physicochemical stabilization of sunflower oil during storage $\left(65^{\circ} \mathrm{C}\right)$. They noticed that garlic extract could significantly stabilize sunflower oil compared to synthetic antioxidants. This result was attributed to different active compounds, particularly phenolic components, in garlic extract.

\section{Conclusion}

According to our observations, the lowest and highest peroxide value was observed in the ethanolic sample extracted with ultrasound at 30 minutes and aqueous extract respectively. Anisidine index rose in all oil samples with increasing storage time. On the first day of storage, the lowest anisidine and totox index was recorded in oil samples containing ethanolic extract. Ethanolic extracts were more effective in preventing oil oxidative rancidity than the other treatments, particularly the synthetic antioxidant and the essential oil. The TBA index was low in the early days of storage. The ethanolic extract treatment had the highest potential to prevent the formation of secondary oxidation products. After 5 days of storage, a decreasing effect was detected on the oxidation rate of sunflower oil containing ethanolic extract treatment with ultrasound at 30 minutes and the essential oil. Since the 
ethanolic extract played a more effective role than the essential oil in preventing oil oxidation, it can, therefore, be a good substitute for synthetic antioxidants in frying oils.

\section{References}

Abdalla AE, Roozen JP. 1999. Effect of plant extracts on the oxidative stability of sunflower oil and emulsion. Food Chem 64: 323-329.

Abdul DA. 2014. Preparation and characterization of pectin from peel of kabad (Citrus medica) Fruit in sulaimani city, Iraqi Kurdistan Region. Int J Curr Res Chem Pharm Sci 142-146.

Agregán R, Lorenzo JM, Munekata PES, Dominguez R, Carballo J, Franco D. 2017. Assessment of the antioxidant activity of Bifurcaria bifurcata aqueous extract on canola oil. Effect of extract concentration on the oxidation stability and volatile compound generation during oil storage. Food Res Int 99(Pt 3): 1095-1102.

Albu S, Jaico E, Paniwnyk L, Lorimer JP, Mason T. 2004. Potential for the use of ultrasound in the extraction of antioxidants from Rosmarinus officinalis for the food and pharmaceutical industry. Ultrason Sonochem 911: 261-265.

AOCS. 1998. Official Methods and Recommended Practice of the American Oil Chemists' Society. 5th Edition, Methods Cd 1d-92, Cd 3-25, Cc 10-95, Cc 7-25, Ce 1b-89, Cd 18-90, Ca 5a-40, Cd 12-57, Cc 13i-96 and Ca 12-55. Champaign: AOCS Press.

Ayoughi f, Barzegar M, Sahari MA, Naghdi Badi H. 2009. Antioxidant effect of dill (Anethum graveolens boiss.) oil in crude soybean oil and comparison with chemical antioxidants. $J$ Med Plants 8(30): 71-83.

Chirinos R, Rogez H, Campos D, Pedreschi R, Larondelle Y. 2007. Optimization of extraction conditions of antioxidant phenolic compounds from mashua (Tropaeolum tuberosum Ruız \& Pavon) tubers. Sep Purif Technol 55: 217-225.

Chung J, Lee J, Choe E. 2004. Oxidative stability of soybean and sesame oil mixture during frying of flour dough. J Food Sci 69(7): 574-578.

Dieffenbacher A, Pocklington WD. 1987. Standard methods for the analysis of oils, fats and derivatives. Int Union Pure Appl Chem. Oxford: Blackw.

Esmaeilzadeh Kenari R, Mehdipoor SZ. 2012. Antioxidant effect of kiwi peel methanolic extract on oxidative stability of sunflower oil. Iran Food Sci Technol Res J 8(2): 245-250.

Gharekhani M, Ghorbani M, Ebrahim-Zadeh MA, Jafari M, Sadeghi Mahunk A. 2009. Effect of leaf extract in preventing oxidation of soybean oil. Electron J Food Process Preserv 2: 85-102.

Hashemi MB, Niakousari M, Saharkhiz MJ, Eskandari MH. 2014. Stabilization of sunflower oil with Carum copticum Benth \& Hook essential oil. J Food Sci Technol 51(1): 142-147.

Hokmollahi F. 2010. Collection, identification and culture of medicinal fungi phellinus from Iran and study of phytochemical antibacterial and antioxidant effects. Shahid Beheshti University. Faculty of Biosciences. MSC Thesis.

Iqbal I, Bhanger MI. 2007. Stabilization of sunflower oil by garlic extract during accelerated storage. Food Chem 100: 246-254.

Johnson JJ, Meyer RF, Krall JM, et al. 2009. Agronomic practices. In: High plains sunflower production handbook. MF-2384. Manhattan, KS: Kansas State Univ., pp. 1-4.

Mallet JF, Cerrati C, Ucciani E, Gamisons J, Gruber M. 1994. Antioxidant activity of plant leaves in relation to their alphatocopherol content. Food Chem 49: 61-65.

Matthaus B. 2006. Utilization of high oleic rapeseed oil for deep fat frying of French fries -compared to other commonly used edible oils. Eur J Lipid Sci-Technol 108(3): 200-211.

Mazaheri Kalahrodi M, Bassiri AR, Jalali H. 2014. Evaluation of antioxidant properties of essential oil of fennel (Foeniculum vulgare) and its effect on the oxidative stability of soybean oil. Iran J Biosyst Eng 45(2): 131-139.

Meena AK, Kandale Ajit, Rao MM, Panda P, Reddy Govind. 2011. A review on citron-pharmacognosy, phytochemistry and medicinal uses. Int Res $J$ Pharm 2(1): 14

Mir-Ahmadi M, Fatemi H, Sahari MA. 2005. Effect of green tea extract on the inhibition of sunflower oil oxidation. Food $\mathrm{Sci}$ Technol 2(7): 61-70.

Namiki M. 1990. Antioxidant antimutagens in food. Crit Rev Food Sci Nutr 29: 273-300.

Oktaya M, Gulcin O, Kufreviog I. 2003. Determination of in vitro antioxidant activity of fennel (Foeniculum vulgare) seed extracts. Lebensm Wiss Technol 36(2): 263-271.

Ozcan MM, Arslan D. 2011. Antioxidant effect of essential oils of rosemary, clove and cinnamon on hazelnut and poppy oils. Food Chem 129(1): 171-174.

Popovich KM. 2008. The influence of natural antioxidants on the oxidative stability of iodine-fortified sunflower oil in the process of storage. Surf Eng Appl Electrochem 44(5): 415-421.

Rehman ZU. 2006. Citruspeel extract. A natural source of antioxidant. Food Chem 99: 450-454.

Sahari MA, Ataii D, Hamedi M. 2004. Characteristics of tea seed oil in Comparison with sunflower and olive oils and its effect as a natural antioxidant. J Am Oil Chem Soc 81: 585-588.

Suja KP, Jayalekshmy A, Arumughan C. 2004. Free radical scavenging behavior of antioxidant compounds of sesame (Sesamum indicum L.) in DPPH system. J Agric Food Chem 52: 912-915.

Suzuki M, Watanabe T, Miura A, Harashima E, Nakagawa Y, Tsuji K. 2002. An extraction solvent optimum for analyzing polyphenol contents by Folin-Denis assay. Nippon Shokuhin Kagaku Kaishi 49: 507-511.

Tahami FA, Bassiri AR, Ghiasi Tazari B, Mahasti P. 2011. Evaluation of antioxidant properties of essential oil of fennel (Foeniculum vulgare) on the stability of soybean oil. J Food Technol Nutr 10 (1): 71-78.

Cite this article as: Okhli S, Mirzaei H, Hosseini SE. 2020. Antioxidant activity of citron peel (Citrus medica L.) essential oil and extract on stabilization of sunflower oil. OCL 27: 32. 